\title{
Relevance and evaluation of the benchmark dose in toxicology
}

\author{
Katarina Baralić*, Dragana Javorac, Evica Antonijević, \\ Aleksandra Buha-Djordjević, Marijana Ćurčić, Danijela Djukić-Ćosić, \\ Zorica Bulat, Biljana Antonijević
}

University of Belgrade - Faculty of Pharmacy, Department of toxicology, „Akademik

Danilo Soldatović", Vojvode Stepe 450, 11000 Belgrade, Serbia

University of Belgrade - Faculty of Pharmacy, Center for toxicological risk assessment,

Vojvode Stepe 450, 11000 Belgrade, Serbia

*Corresponding author: e-mail: katarinab@ pharmacy.bg.ac.rs

\begin{abstract}
This paper aims to present the importance of the benchmark dose (BMD) as a point of departure (the lowest dose or concentration in the experiment that deviates from the response that differs from the normal response) in toxicological risk assessment, as well as to present commonly used software for its calculation (BMDS and PROAST). Benchmark dose is defined as a statistical lower confidence limit of a dose that results in a small change in effect (5-10\%) in comparison with the control value. The BMD approach is considered a substitution for the NOAEL approach, which uses the highest observed no-effect level (NOAEL) to obtain the reference dose. The BMD approach is a methodically more forward-thinking technique than the NOAEL approach because it has statistical power and provides a wide range of dose-response relationships and allows the determination of their uncertainty and variability. Moreover, the BMD approach contributes to the reduction of experimental animals in toxicity studies. Therefore, the European Food Safety Authority (EFSA) recommends the use of $\mathrm{BMDL}_{10}$ values for quantal and $\mathrm{BMDL}_{05}$ for continuous data.
\end{abstract}

Keywords: toxicology, risk assessment, benchmark dose, PROAST, BMDS 


\section{Human health risk assessment}

Human health risk assessment is the process of data analysing to determine whether a chemical might lead to adverse effects in the exposed subjects $(1,2)$. It includes the characterization and quantification of potential harmful effects on human health associated with exposure to chemicals (1-3). Four steps of risk assessment are: hazard identification (assessment of whether the agent produces a toxic effect), hazard characterization (dose-response modelling), exposure assessment, and risk characterization (4). One of the main objectives of risk assessment is to establish acceptable levels of human exposure, the so-called 'safe' values, necessary for safety evaluation of impurities in active pharmaceutical ingredient (API) or drug product, as well as setting up regulations regarding industrial and environmental chemicals, food additives, pesticide residues, etc. (3). The next crucial step in the process of obtaining safe values is the determination of Point of Departure (POD) - the lowest dose or concentration that causes a response in the experiment that deviates from the normal response and poses toxicological relevance. To eliminate the differences between the experimental data, POD must be extrapolated or modified by the safety factors. In this step, the following uncertainties should be considered: differences between species, differences within species, differences in length of exposure, database quality, etc. $(5,6)$.

Two main approaches can be used for estimating POD, No Observable Effect Level (NOAEL), and Benchmark Dose (BMD) approach (3, 6).

This paper aims to present the use of BMD as a Point of Departure in estimating the dose-response relation, compare BMD with the NOAEL approach underlining their most important advantages and disadvantages, as well as to describe the most commonly used software for BMD calculation (BMDS and PROAST).

\section{BMD history}

Crump was the first to propose BMD approach in 1984. Originally, this methodology was intended only for quantal data (7). Nevertheless, in 1995, its use was extended to include continuous data as well (8). Somewhat later, a regression approach was introduced, with the aim to obtain POD even at low dose levels $(9,10)$. In 2005, the European Food Safety Agency (EFSA) recommended the application of BMD for evaluation of non-threshold effects (i.e. for genotoxic and carcinogenic substances) (11). In 2009, the recommendation was broadened to include the evaluation of risks of all substances, using experimental and epidemiological data (12). Today, even the World Health Organization (WHO) recommends the use of BMD in human health risk assessment (13).

By definition, BMD is considered a dose that results in a small change in effect (5$10 \%$ ) in comparison with the control value. The variability and uncertainty of the data are taken into account by the determination of the statistical lower and upper confidence 
limits. The statistical lower confidence limit was formerly called the benchmark dose (7), but soon became recognised as a BMD lower limit (BMDL) (12). This methodology is considered a substitute for the NOAEL approach, which uses NOAEL, or lowest observed adverse effect level (LOAEL) (4).

\section{NOAEL approach for POD calculation}

NOAEL approach can be applied to all toxicological effects under the condition that they have a threshold. It has long been used in regulatory processes for assessing the health risks of substances in food, especially to determine tolerable daily intake (TDI) or tolerable weekly intake (TWI) for contaminants, permitted daily exposure (PDE) for elemental impurities and residual solvents in medicinal products, as well as acceptable daily intake (ADI) for food additives and pesticide residues (12).

In the NOAEL approach, for each monitored effect, the highest non-toxic dose is determined. The lowest relevant NOAEL of all the toxic effects identified in the study is marked as the critical NOAEL of the study.

In other words, NOAEL represents the highest tested dose that does not lead to a toxic effect in a particular experiment. NOAEL's numerical value highly depends on the choice of dose levels in the study design process, as well as on the study ability to detect adverse effects. Given that the number of animals used in studies is limited, and that the test methods are not sensitive enough to detect low effects, the experiments, particularly older ones, usually resulted in very high NOAEL values. In the case that significant effect is observed at all selected dose levels, LOAEL may be used in further risk assessment, including additional safety factors (12).

Thus, in the NOAEL approach, the shape of the dose-response curve is not taken into account. Moreover, this approach heavily depends on the choice of dose intervals and the number of experimental animals, together with the sensitivity of the methods to identify the critical effect (12). Particularly, this concept is not sufficiently reliable for the risk evaluation in the case of genotoxic carcinogens, where it is assumed that even one molecule might induce toxic response relevant to humans. It is generally accepted that chemical risk assessment in animal studies at human exposure levels can be improved by creating a dose-response curve to better characterize and quantify potential risks (14).

\section{BMD approach for POD calculation}

The BMD approach is of particular importance for 1) situations where NOAEL cannot be identified; 2) determination of the Margin of Exposure (MOE) in the case of non-threshold effects (genotoxic and carcinogenic substances); as well as 3) assessment of the dose-response ratio of epidemiological studies data (12).

The BMD approach has mostly been applied in the developmental toxicity studies $(12,15-18)$ and neurotoxicity $(12,15,18,19)$. In addition, recently published data indicate 
the other ways in which the BMD approach could be applied in toxicology (18,20-29). The experience of our research group includes the use of a BMD approach in evaluating the toxic effects of decabrominated diphenyl ether BDE-209 in subacute orally exposed Wistar rats (Figure 1A) $(25,28)$, as well as polychlorinated biphenyls after subacute oral exposure of rats $(23,27)$. Also, for the first time, Antonijevic et al. have introduced BMD to assess the effectiveness of antidote in a study in which acute i.m. dichlorvos exposure of rats was followed by the reactivation of acetylcholinesterase in erythrocytes and diaphragm by K203 and K027 oximes (Figure 1B) $(24,26,29)$. It can also be applied to establish health based exposure limits in risk identification in the process of manufacture of various medicinal products in shared facilities (30). Furthermore, the BMD approach can be used to assess risks in ecotoxicology (18,31). For example, in ecotoxicological toxicity tests (i.e. reproductive toxicity tests on daphnia and oyster larvae), conducted to investigate the impact of certain pollutants or their mixtures on the environment (18).

Benchmark modelling is relatively simple. Experimental data are fitted into the flexible mathematical models. The next step is the determination of a dose linked to a defined response level. The defined response level is marked as Benchmark Response (BMR), with BMD being its corresponding dose (12). The advantage was given to a $95 \%$ lower BMD confidence limit (BMDL), until, in 2017, EFSA recommended describing the entire confidence interval, including the BMD upper limit, BMDU, implying that twosided approach should be set in software for calculations $(32,33)$.

The BMD approach can be used in the assessment of nearly all toxicological effects. It includes taking into account all dose-response data during the estimation of the total dose-response curve shape for a given endpoint.

The first step in the BMD approach includes determination of low but measurable response level (e.g. 5\%, 10\%, or higher increase or decrease in response in comparison with the response in the control group, depending on the effect), i.e. BMR. The next step involves fitting a group of dose-response models and calculating BMD, BMDL, and BMDU for those that illustrate the data following statistical criteria. This means that the minimum dataset for BMD calculation should show a biologically/statistically significant dose-related trend for the particular endpoint. This step results in a range of BMDL values for each examined toxic effect. BMDL is selected for each investigated effect and the critical BMDL value of the study is determined from the range of BMDL values for the various observed effects.

The BMD approach can be applied to any toxic effect observed in appropriate studies, while the toxic effect with the lowest BMDL is considered the critical effect of the study. Based on the review of numerous experimental studies, Allen et al. (1994) deduced that, amongst the tested BMD levels, BMDL05 can be characterized as the most similar to the NOAEL values determined by statistical tests (16). Participants in a BMD workshop (Parma, Italy, 2010) convened to investigate whether NOAEL could be 
substituted with the BMD concluded that BMDL05 or BMDL10 should be applied to all quantal non-carcinogenic toxic effects (34). Furthermore, EFSA proposes that BMR of $10 \%$ (BMDL10) should be used for quantal and BMR of 5\% (BMDL05) for continuous data (12).
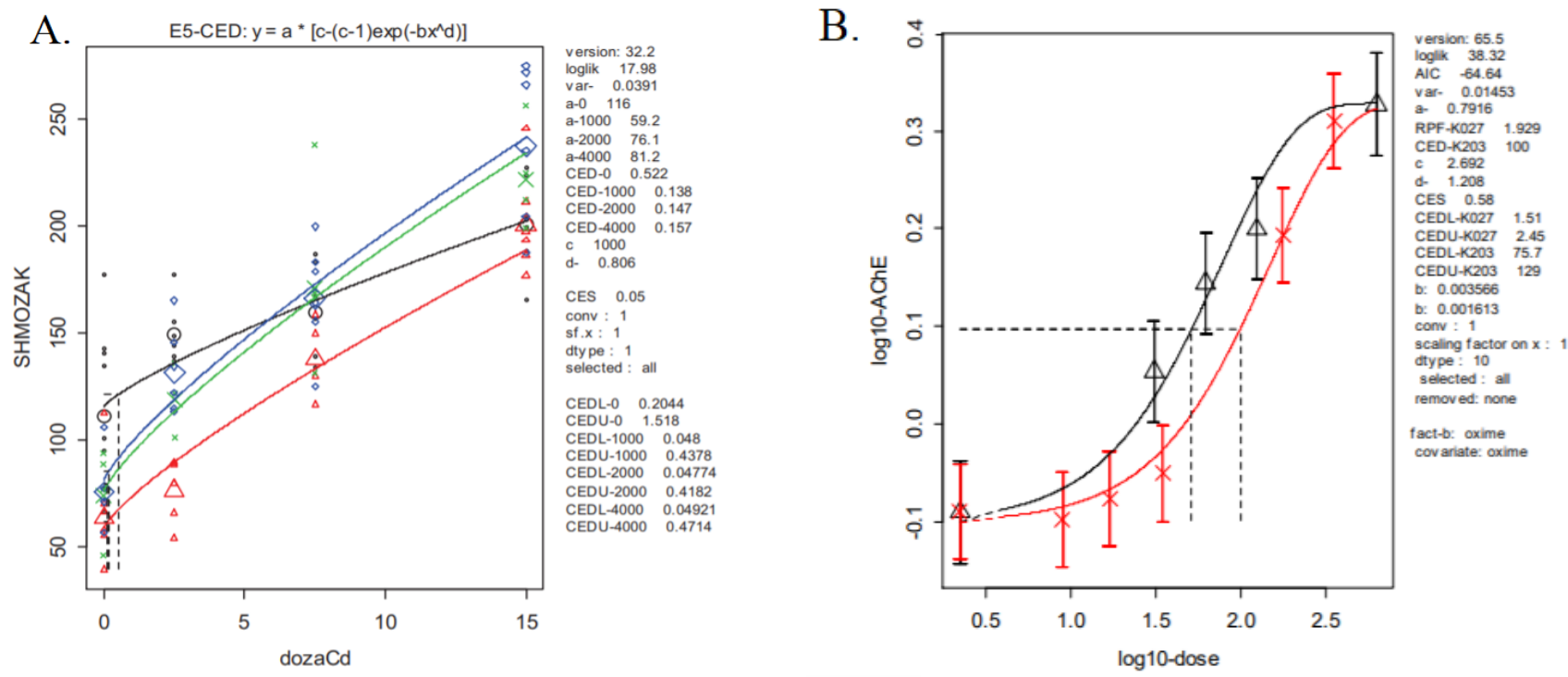

Figure 1. The example of the Benchmark approach (PROAST software); In the PROAST report for continuous data, the terms critical effect size (CES) and critical effect dose (CED) are used instead of the term Benchmark response (BMR) and Benchmark dose (BMD). (A) Effect of cadmium and cadmium in combination with decabromodiphenyl ether (BDE209) in doses $1000,2000,4000 \mathrm{mg} / \mathrm{kg} \mathrm{bw} / \mathrm{day}$ on the concentration of -SH groups in brain homogenates of Wistar rats; (B) Ratio of oxime K027 (triangles, black curve) and oxime K203 (crosses, red curve) doses and ACHE activity in the erythrocyte mucus of Wistar rats poisoned with dichlorvos. The curves represent a fitted exponential model, which includes the calculation of the relative potency factor (RPF) as a parameter of the model. RPF expresses the Critical Effect Dose (CED) of oxime K027 versus CED of oxime K203 (RPF> 1, higher potency, lower CED). The values of RPF-K027 (unnamed number), CED-K203 $(\mu \mathrm{mol} / \mathrm{kg}$ ) together with $90 \%$ confidence interval are shown in the legend to the right of each graph. The vertical and horizontal dashed lines represent RPF-K027 and CEDK203 for the critical effect size (CES) of 58\%.

Slika 1. Primer benchmark pristupa (PROAST softver); U izveštaju PROAST softvera za kontinuirane podatke koriste se pojmovi veličina kritičnog efekta (engl. critical effect size, CES) i kritična doza (engl. critical effect dose, CED) umesto termina benchmark odgovor (engl. Benchmark response BMR) i benchmark doza (engl. Benchmark dose, BMD), redom. (A) Dejstvo kadmijuma i kadmijuma u kombinaciji sa dekabromovanim difeniletrom (BDE209) u dozama 1000, 2000, $4000 \mathrm{mg} / \mathrm{kg}$ t.m./dan na koncentraciju -SH grupa u homogenatima mozga Wistar 
pacova; (B) Odnos doze oksima K027 (trouglovi, crna kriva) i oksima K203 (krstići, crvena kriva) i ACHE aktivnosti u eritrocitima Wistar pacova trovanih dihlorvosom. Krive predstavljaju fitovani eksponencijalni model, koji uključuje izračunavanje relativnog faktora potentnosti (engl. relative potency factor, RPF) kao parametra modela. RPF izražava CED oksima K027 nasuprot CED oksima K203 (RPF > 1, veća potentnost, niži CED). Vrednosti RPF-K027 (neimenovani broj), CED-K203 ( $\mu \mathrm{mol} / \mathrm{kg}$ ) zajedno sa intervalom pouzdanosti od $90 \%$ prikazani su u legendi desno od svakog grafika. Vertikalne i horizontalne isprekidane linije predstavljaju RPF-K027 i CED-K203 za CES od $58 \%$.

In the BMD approach, statistical methods are used to extract the information from a whole data set, rather than comparing subgroups of the data. Additionally, the BMD approach can interpolate among administered doses, which is not the case with the NOAEL approach. This means that BMDL is linked to a predefined effect size for which the suitable dose is estimated. Contrarily, NOAEL represents a predefined dose, while the corresponding potential effect size is not calculated. Therefore, BMDL provides more information than NOAEL. The BMD approach is characterized by an uncertainty estimate in the calculated BMD: it is expressed by the BMD confidence interval, which is not usually done in the NOAEL approach. This distinction between the two approaches is particularly important in cases where there is a limited number of data or values are very scattered. Although NOAEL approach can often be applied in such cases, uncertainty in the resulting values is not calculated in most of the cases $(12,32,33)$.

\section{The impact of the sample size on NOAEL and BMDL}

One of the major differences between the NOAEL and BMD approach is how they are affected by the sample size $(7,18)$. In the NOAEL approach, the responses of treated groups are compared with the response of the control group. The likelihood of obtaining a statistically significant difference lowers with the decrement in experimental animals' number and thus results in a higher NOAEL value and consequently, higher recommended reference values concerning human health and safety. Contrariwise, in the BMD approach, BMDL increases with the increase of experimental animals' number per dose group. Having in mind that BMDL represents the lower BMD confidence interval, a larger study will have a smaller BMD confidence interval as an outcome and, therefore, a higher BMDL value (18).

\section{BMD approach and 3R rule}

The BMD approach could be counted a significant step forward regarding the $3 \mathrm{R}$ rule - replacing experimental animals wherever possible by alternative methods or species that are lower on the phylogenetic scale, reducing the number of animals, and refinement of experimental procedures to diminish pain, suffering or lasting harm of animals $(35,36)$. 
BMD approach supports 3R rule, especially the reduction of experimental animals' number, having in mind that it is a scientifically better and more precise method of doseresponse data analysis compared to the NOAEL approach. The reduction of experimental animal numbers can be contributed in two ways. Firstly, the information (e.g. POD) that can be obtained from a data set is more accurate when applying the BMD approach compared to the NOAEL. Secondly, the same quality information (e.g. the accuracy of the obtained POD) can be achieved by using fewer animals $(35,36)$.

\section{Software packages for BMDL determination}

The two most commonly used BMDL software packages are BMDS (Benchmark Dose Software, BMDS), created by the US Environmental Protection Agency (US EPA), and PROAST, created by the National Institute of Public Health and the Netherlands National Institute for Public Health and the Environment (RIVM) $(33,34)$.

The main differences between the two software packages include the following:

- The predefined settings in PROAST software include the log-normal data distribution, while, in the BMDS software, normal distribution of continuous data is set as a default (34).

- Currently, BMDS software does not allow covariance to be included in the analysis, while this possibility exists in PROAST (34).

- BMDS is not suitable for studies with a large number of individual data (e.g. epidemiological studies) because there is a limit of the number of data that can be inserted (34).

- The same exponential group of models can be entered into BMDS and PROAST software (Table I). BMDS software provides results for each model entered, allowing the user to choose the optimal one, while PROAST automatically selects it (34).

Other differences include the interface of the two software. While BMDS can be run immediately and supported by Windows only, PROAST requires the installation and prior familiarization with $\mathrm{R}$ software. In addition to Windows, it is also supported by Linux and Mac operating systems $(33,34)$. Other significant differences between these two software packages can be found in references 33 and 34 .

In PROAST software, the selection of the optimal model within the exponential and/or Hill family of models is made by applying Akaike information criteria (AIC) $(12,33,37)$. According to these criteria, the model with the smallest AIC fits data the best. Thus, the use of the smallest AIC is recommended even when the differences between the values are very small (37). Dose dependence is confirmed in the case when AIC value of a specific model is lower than the null model AIC value for more than two units (AICmin < AICnull - 2). Having in mind that, in the case of the null model, there is no 
dose-dependence, that implies that the dose-effect curve represents the horizontal line (y = a). Furthermore, the lowest AIC model value must not surpass the AIC value of the specific full model by more than two units (AICmin < AICfull + 2) $(29,35)$. In the mathematical equations of the model, $y$ represents the intensity of the effect, $x$ represents the dose, while the constants var, a, b, c, and d are the parameters of the curve obtained by fitting the model with dose-effect data. Parameter var represents the variance within the group. Parameter a represents the effect at zero dose of the so-called background effect (vertical curve position parameter), while parameter $b$ represents chemical potency (horizontal curve position parameter). Parameter $\mathrm{c}$ represents maximum effect intensity ( $\mathrm{M}=\mathrm{c}$ for ascending curves, $\mathrm{M}=1 / \mathrm{c}$ for descending curves) in relation to the background effect level (curve shape parameter), while d represents the slope of the curve (curve shape parameter) $(12,29,33,37)$.

Table I Recommended models in the BMD approach

Tabela I Preporučeni modeli za izračunavanje BMD

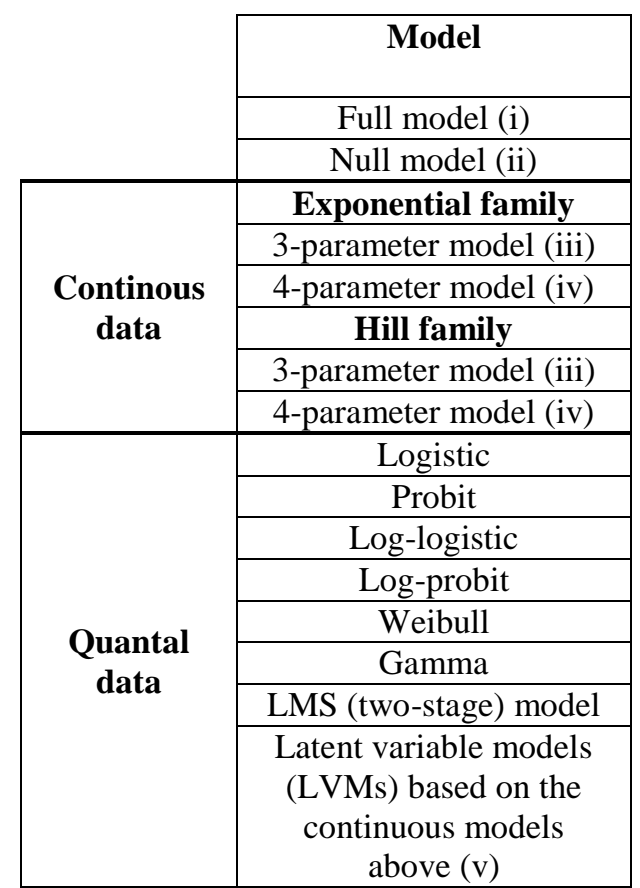

(i): The full model will result in the maximum possible value of the log-likelihood (given the statistical assumptions) for the data set considered.

(ii): The null model can be regarded as a model that is nested within any dose-response model: it reflects the situation of no dose response (= horizontal line).

(iii): Called model 3 in PROAST, and similarly (for the exponential model) in BMDS.

(iv): Called model 3 in PROAST, and similarly (for the exponential model) in BMDS.

(v): The latent variable models are implemented in PROAST. 


\section{Conclusion}

The BMD approach can be considered a methodically more forward-thinking technique in comparison with NOAEL approach. It has statistical power, provides a wide range of dose-response data, and allows calculation of their uncertainty and variability. It also provides the ability to process old datasets, contributing to the reduction of experimental animals. Due to its advantages over the NOAEL approach, the application of the BMD approach is recommended in the assessment of genotoxic and carcinogenic substances, but also generally in toxicity assessment. It can be used for threshold, but also non-threshold effects of a vast number of substances that could threaten not only human health but also the environment. In that case, the NOAEL approach would only be used if it were not possible to fit the data in the models of available software packages.

\section{References}

1. National Research Council. Risk assessment in the federal government: managing the process. National Academies Press; 1983. 25p.

2. National Research Council. Science and judgment in risk assessment. National Academies Press; 1994. 18p.

3. Öberg M. Benchmark dose approaches in chemical health risk assessment in relation to number and distress of laboratory animals. Regul Toxicol Pharmacol. 2010;58(3):451-4.

4. Jensen SM, Kluxen FM, Ritz C. A Review of Recent Advances in Benchmark Dose Methodology. Risk Anal. 2019;39(10):2295-315.

5. Barnes DG, Dourson M, Dourson M, Preuss P, Barnes DG, Bellin J, et al. Reference dose (RfD): Description and use in health risk assessments. Regul Toxicol Pharmacol. 1988;8(4):471-86.

6. Đukić-Ćosić D, Antonijević B. Zašto je potrebna toksikološka procena rizika za kozmetički proizvod? Arh Farm (Belgr). 2018;971-89.

7. Crump KS. A new method for determining allowable daily intakes. Toxicol Sci. 1984;4(5):854-71.

8. Crump KS. Calculation of Benchmark Doses from Continuous Data. Risk Anal. 1995;15(1):79-89.

9. Edler L, Poirier K, Dourson M, Kleiner J, Mileson B, Nordmann H, et al. Mathematical modelling and quantitative methods. Food Chem Toxicol. 2002;40(2-3):283-326.

10. Wheeler MW, Park RM, Bailer AJ, Whittaker C. Historical Context and Recent Advances in Exposure-Response Estimation for Deriving Occupational Exposure Limits. J Occup Environ Hyg. 2015;12:S7-17.

11. European Food Safety Authority (EFSA). Opinion of the Scientific Committee on a request from EFSA related to A Harmonised Approach for Risk Assessment of Substances Which are both Genotoxic and Carcinogenic. EFSA J. 2005;3(10):282.

12. Barlow S, Chesson A, Collins J, Flynn A, Hardy A, Klaus-Dieter J, et al. Use of the benchmark dose approach in risk assessment. EFSA J. 2009;1150:1-72. 
13. Bernauer U, Bodin L, Chaudry Q, Coenraads PJ, Dusinka M, Ezendam J, Gaffet E, Galli CL, Granum B, Panteri E, Rogiers V. " The SCCS note of Guidance for the testing of cosmetic ingredients and their safety evaluation-10th Revision" SCCS/1602/18-Final version (2018).

14. Smith M. Food Safety in Europe: Risk assessment of chemicals in food and diet. Food Chem Toxicol. 2002;40:2-3.

15. Gaylor DW. Incidence of developmental defects at the no observed adverse effect level (NOAEL). Regul Toxicol Pharmacol. 1992;15(part 2):151-60.

16. Allen B. Dose-Response Assessment for Developmental Toxicity II. Comparison of Generic Benchmark Dose Estimates with No Observed Adverse Effect Levels. Vol. 23, Fundamental and Applied Toxicology. 1994. p. 487-95.

17. Krewski D, Zhu Y, Fung KY. Benchmark doses for developmental toxicants. Inhal Toxicol. 1999;11(6-7):579-91.

18. Filipsson AF, Sand S, Nilsson J, Victorin K. The Benchmark Dose Method - Review of Available Models, and Recommendations for Application in Health Risk Assessment. Crit Rev Toxicol. 2003;33(5):505-42.

19. Gaylor DW, Slikker W. Modeling for Risk Assessment of Neurotoxic Effects. Risk Anal. 1994;14(3):333-8.

20. Fechter LD, Chen G Di, Rao D, Larabee J. Predicting exposure conditions that facilitate the potentiation of noise-induced hearing loss by carbon monoxide. Toxicol Sci. 2000;58(2):315-23.

21. Markowski VP, Zareba G, Stern S, Cox C, Weiss B. Altered operant responding for motor reinforcement and the determination of benchmark doses following perinatal exposure to low-level 2,3,7,8-tetrachlorodibenzo-p-dioxin. Environ Health Perspect. 2001;109(6):621-7.

22. Luyendyk JP, Shores KC, Ganey PE, Roth RA. Bacterial lipopolysaccharide exposure alters aflatoxin B1 hepatotoxicity: Benchmark dose analysis for markers of liver injury. Toxicol Sci. 2002;68(1):220-5.

23. Buha A, Antonijević B, Bulat Z, Jaćević V, Milovanović V, Matović V. The impact of prolonged cadmium exposure and co-exposure with polychlorinated biphenyls on thyroid function in rats. Toxicol Lett. 2013;221(2):83-90.

24. Antonijevic E, Musilek K, Kuca K, Djukic-Cosic D, Andjelkovic M, Djordjevic AB, et al. Comparison of oximes K203 and K027 based on Benchmark dose analysis of rat diaphragmal acetylcholinesterase reactivation. Chem Biol Interact. 2019;308(May):385-91.

25. Ćurčić M, Tanasković S, Stanković S, Janković S, Antunović M, Djordjević S, et al. Odnos hepatotoksičnosti i doze dekabromovanog difeniletra u ciljnom tkivu kod subakutno izloženih Wistar pacova. Vojnosanit Pregl. 2015;72(5):405-13.

26. Antonijevic E, Musilek K, Kuca K, Djukic-Cosic D, Curcic M, Miladinovic DC, et al. Dose-response modeling of reactivating potency of oximes K027 and K203 against a direct acetylcholinesterase inhibitor in rat erythrocytes. Food Chem Toxicol. 2018;121(August):224-30.

27. Buha A, Antonijević B, Milovanović V, Janković S, Bulat Z, Matović V. Polychlorinated biphenyls as oxidative stress inducers in liver of subacutely exposed rats: Implication for dose-dependence toxicity and benchmark dose concept. Environ Res. 2015;136:309-17. 
28. Ćurčić M. Subakutna toksičnost smeše dekabromovanog difeniletra i kadmijuma kod pacova. 2015. (Doctoral dissertation, Univerzitet u Beogradu-Farmaceutski fakultet).

29. Antonijević E. Antidotska efikasnost novosintetisanih oksima k203 i k027 kod pacova akutno trovanih dihlorvosom. 2019. (Doctoral dissertation, Univerzitet u Beogradu-Farmaceutski fakultet).

30. EMA. Guideline on setting health based exposure limits for use in risk identification in the manufacture of different medicinal products in shared facilities. 2014;44(November).

31. Bailer AJ, Oris JT. Modeling reproductive toxicity in Ceriodaphnia tests. Environ Toxicol Chem. 1993;12(4):787-91.

32. Haber LT, Dourson ML, Allen BC, Hertzberg RC, Parker A, Vincent MJ, et al. Benchmark dose (BMD) modeling: current practice, issues, and challenges. Crit Rev Toxicol. 2018;48(5):387-415.

33. Hardy A, Benford D, Halldorsson T, Jeger MJ, Knutsen KH, More S, et al. Update: use of the benchmark dose approach in risk assessment. EFSA J. 2017;15(1):1-41.

34. Use of BMDS and PROAST software packages by EFSA Scientific Panels and Units for applying the Benchmark Dose (BMD) approach in risk assessment. EFSA Support Publ. 2017;8(2).

35. Slob W. Benchmark dose and the three Rs. Part I. Getting more information from the same number of animals. Crit Rev Toxicol. 2014;44(7):557-67.

36. Slob W. Benchmark dose and the three Rs. Part II. Consequences for study design and animal use. Crit Rev Toxicol. 2014;44(7):568-80.

37. Davis JA, Gift JS, Zhao QJ. Introduction to benchmark dose methods and U . S . EPA's benchmark dose software ( BMDS ) version 2.1.1. Toxicol Appl Pharmacol. 2011;254(2):181-91. 


\title{
Značaj i procena benchmark doze u toksikologiji
}

\author{
Katarina Baralić*, Dragana Javorac, Evica Antonijević, \\ Aleksandra Buha-Đorđevic, Marijana Ćurčić, Danijela Đukić-Ćosić, \\ Zorica Bulat, Biljana Antonijević
}

\begin{abstract}
Univerzitet u Beogradu - Fakultet za farmaciju, Katedra za toksikologiju „Akademik
Danilo Soldatović”, Vojvode Stepe 450, 11000 Beograd, Srbija

Univerzitet u Beogradu - Fakultet za farmaciju, Centar za toksikološku procenu rizika, Vojvode Stepe 450, 11000 Beograd, Srbija
\end{abstract}

*Autor za korespondenciju, e-mail: katarinab@pharmacy.bg.ac.rs

\section{Kratak sadržaj}

Cilj ovog rada je da predstavi značaj granične benchmark doze (engl. benchmark dose, BMD) kao polaznog doznog nivoa (najniže doze ili koncentracije u eksperimentu koja odstupa od normalnog odgovora) u toksikološkoj proceni rizika, kao i da prikaže najčešće korišćene softvere za njeno izračunavanje (BMDS i PROAST). Benchmark doza predstavlja statističku donju granicu pouzdanosti doze koja dovodi do malog povećanja efekta (5-10\%) u odnosu na kontrolnu vrednost. Benchmark pristup predstavlja alternativu NOAEL (engl. no observed adverse effects level, NOAEL) pristupu, u kome se u svrhu dobijanja referentnih vrednosti koristi najviša doza koja ne izaziva štetan efekat. Benchmark pristup naučno je napredniji metod od tradicionalnog NOAEL pristupa, jer je statistički utemeljen, daje širok opseg podataka o odnosu doza-odgovor i omogućava kvantifikaciju njihove nesigurnosti i varijabilnosti. Takođe, BMD pristup doprinosi smanjenju broja eksperimentalnih životinja u toksikološkim studijama. Samim tim, Evropska agencija za bezbednost hrane (EFSA) preporučuje primenu doza BMDL 10 za kvantalne i BMDL 05 za kontinuirane podatke.

Ključne reči: toksikologija, procena rizika, benchmark doza, PROAST, BMDS 